\title{
Enkele prinsipiële fasette: die wiskunde en paradigmas in die ekonomiese wetenskap
}

\author{
W.A. Naudé \\ Departement Ekonomie \\ Potchefstroomse Universiteit vir $\mathrm{CHO}$ \\ POTCHEFSTROOM
}

\begin{abstract}
It is argued in this paper that the development of mathematics has had a profound effect upon the research paradigms of economics. Economists' early attempts to imitate the natural sciences have led then to an increasing quantification of their own science. with the consequence that recent developments in mathematics, such as the Theory of Chaos and the Theory of (atastrophe, logether with the implications from quantum physics, are causing a paradigm shift in economics. This paradigm shift has been turning away from a positivistic view' of economic science towards a normative one a view where there seems to be greater acceptance of the principle that science cannot be free from value judgements. For the ('hristian economist these developments are to be welcomed. In the light of this, the paper concludes with a Scriptural perspective on the role of mathematics in economics.
\end{abstract}

"God used beautiful mathematics in creating the world"

- (Dirac, 1963:125).

\section{Inleiding}

Die enigste fundamentele wet in die ekonomiese wetenskap is dat daar vir elke uitgawe 'n inkomste moet bestaan (Pyatt, 1988). Dié wet, wat al deur die antieke Grieke en Romeine beskryf is, is eers in die 17de eeu as 'n grondslag vir die ekonomiese wetenskap gebruik (Stone, 1986). William Petty, Gregory King en Francios Quesnay vertolk die wet as 'n kringloop van geld en goedere wat al die deelnemers in 'il ekonomie insluit. Die moderne ekonomiese wetenskap, wat op dié fundamentele wet gebou is, poog om die geheel van die mens se ekonomiese aktiwiteit (wat die komplekse interafhanklikhede wat menslike gedrag in die ekonomiese sfeer insluit) te verklaar. Dié waagmoedige taak wat die ekonomiese 
wetenskap homself ten doel gestel het, het gelei tot die probleem van algemene ewewig, wat in 1874 deur Leon Walras geformuleer is.

Walras (1874) se probleem was om te bewys dat indien die ekonomie uit $n$-aantal verbruikers en $m$-aantal produsente bestaan, daar op die markte 'n vektor van pryse tot stand sou kom wat sou verseker dat vraag en aanbod op al die markte gelyk sou wees. Gedurende sy leeftyd kon Walras egter glad nie so 'n bewys vind nie. Eers nagenoeg 70 jaar later het Arrow en Debreu (1954) 'n bewys voorsien. As gevolg van die ingewikkeldheid van Walras se probleem moes ekonome soos Arrow en Debreu (1954) van gevorderde wiskundige tegnieke gebruik maak om die bestaan van 'n ewewigsprysvektor te bewys (wiskundige tegnieke soos onder andere Brouwer se vastepuntstelling en veralgemenings daarvan deur Kakutani (1941) is gebruik).

Die gevolg van Arrow en Debreu se deurbraak het uitgekring deur die ekonomiese wetenskap, en in Debreu (1991:1) se woorde "economic theory entered a phase of intense mathematization that profoundly transformed the profession".

Die kwantifisering van die ekonomiese wetenskap het aanvanklik onder die invloed van die empiriese en logiese positiwisme plaasgevind. Walras en sy navolgers het geglo dat, net soos in die natuurwetenskappe, daar absolute waarhede in die ekonomie bestaan wat net deur die mens ontdek moes word. Hierdie reëls kon volgens Walras in wiskundige vorm voorgestel word. Vooronderstellinge moes sover moontlik uitgeskakel word (Lastis, 1976:14).

Mettertyd het ontwikkelinge in die wiskunde egter tot verskillende paradigmas in die ekonomie aanleiding gegee. Enkele fasette hiervan word in hierdie artikel vanuit 'n Skriftuurlike perspektief bespreek. Die bespreking sal soos volg verloop: in die volgende afdeling word die vernaamste paradigmas in die ekonomiese wetenskap uiteengesit, in afdeling 3 word onlangse ontwikkelinge in die wiskunde bespreek, en word die invloed daarvan op die paradigmas in die ekonomiese wetenskap geidentifiseer, en in afdeling 4 word enkele Skrifturlike fasette van die kwantifisering van die ekonomiese wetenskap belig. Die artikel sluit af met met 'n kort samevatting.

\section{Paradigmas in die ekonomiese wetenskap}

In dié afdeling sal sommige van die vernaamste paradigınas in die ekonomiese wetenskap kortliks bespreek word. Dit is nie die doel om al die verskillende paradigmas binne ekonomiese denkskole te bespreek nie, maar net die bekendste en invloedrykste paradigmas en denkskole. In dié opsig is daar ook 'n uitsondering, 
en dit is dat die Marxistiese teorie nie hier bespreek word nie. Die redes hiervoor is dat die Marxistiese ekonomiese teorie, in teenstelling met die ander teorieë, nie eintlik kwantifiseer nie. ${ }^{1}$ Geen paradigma-verandering in dié teorie het as gevolg van veranderinge in die wiskunde voorgekom nie. Verder is daar alreeds heelwat oor die paradigmas in die Marxistiese teorie geskryf, veral binne 'n politieke konteks.

\subsection{Die Neoklassieke paradigma}

Die Neoklassieke paradigna, waarbinne Walras geteoretiseer het, het die bestaan van 'n "rational economic man" aanvaar (Hodgson, 1990). Deur die ontleding van die optrede van individuele verbruikers en produsente, kom die Neoklassieke ekonome tot die gevolgtrekking dat inmenging deur die owerheid in die ekonomie ongewens is; die ekonomie moes gevolglik aan markkragte - Adam Smith se "invisible hand" - oorgelaat word. Hierdie geloof in markte het die Neoklassieke ekonome gedurende die Depressiejare van die dertigerjare in die onvermoë gelaat om werkloosheid te verklaar (Shaw, 1988:2).

Keynes (1936) verwerp die aannames van die Neoklassieke ekonome en beveel aktiewe owerheidsinmenging aan as 'n oplossing vir werkloosheid. Neoklassieke ekonome soos Hansen en Hicks interpreteer Keynes se teorie sodanig dat dit deur ekonome as 'n spesiale geval van die Neoklassieke teorie beskou is (Shaw, 1988: 6). Eers later sou Clower (1965), Leijonhufvud (1968) en ander onder die vaandel van Neo-Keynesianisıne beswaar maak teen dié kaping en verdraaiing van Keynes se idees deur die Neoklassieke ekonome. Teen dié tyd was die invloed van die Neoklassieke skool egter alreeds so gewortel in die ekonomiese wetenskap, dat die meeste universiteitskursusse in ekonomie alreeds die Neoklassieke teorie as kern bevat het.

Die aannames van die moderne Neoklassieke ekonomie kan volgens Dugger (1983:75) soos volg saamgevat word

* Indien Say se Wet ${ }^{2}$ geld, is aktiewe inmenging deur die owerheid op markte onnodig oin volledige indiensname te bewerkstellig.

* Indien lone en pryse ten volle buigsaam is, is loon en prysbeheer onnodig.

I Dat die Marxisme egter nie groter kwantifisering kan vryspring nie, blyk uit 'n onlangse stelling van Dunne (1991:7) dat "Marx would have been interested in developing a quantitative Marxism, given the tools and equipment available today".

2 Volgens Say sal aanbod (of produksie) self die vraag daarna skep deurdat die produksiefaktore se vergoeding presies identies is aan die waarde wat hul tot produksie gevoeg het 
* Indien onafhanklike ondernemers wins maksimeer onder toestande van volmaakte mededinging sonder die aanwesigheid van eksternaliteite, sal markkragte hul optrede sodanig lei dat geen owerheidsinmenging nodig sal wees nie

* Indien verbruikers rasioneel optree volgens hul eie vrye wil en oor volledige inligting beskik, sal geen owerheidsinmenging nodig wees nie

'n Radikale denkskool wat die afgelope twee dekades uit die Neoklassieke skool ontwikkel het, is die Nuwe Klassieke Ekonome. Hierdie skool, onder leiding van Robert Lucas, verhef die beginsel van die 'rasionele ekonomiese mens' tot die uiterste, en stel dat die rasionele mens 'rasionele verwagtinge' van die toekoms vorm. Die beleidsaanbeveling wat hulle hieruit put, is dat enige inmenging deur die owerheid, hetsy direk of deur monetêre of fiskale beleid, nutteloos sal wees om indiensname en produksie in die ekonomie te beïnvloed (Lucas, 1972:118). Binne ' $n$ historiese konteks kan hierdie denkskool gesien word as die Neoklassieke skool se reaksie teen die Keynesiaanse teorie se beklemtoning dat die onsekerheid van die toekoms daartoe kan lei dat individue en ondernemers verwagtingsfoute begaan en kontrakte teen sub-optimale voorwaardes kan sluit. Hierdie 'verwagtingsfoute' kan tot onstabiliteit in die vorm van werkloosheid en inflasie lei (Clower \& Leijonhufvud, 1975:186-188).

\subsection{Monetarisme en die Oostenrykse skool}

Die Neoklassieke paradigma van die 'rasionele ekonomiese mens' en die geloof dat die ekonomiese wetenskap ook soos die natuurwetenskappe sekere absolute reëls het wat ontdek moes word, het daartoe gelei dat die Neoklassieke ekonome natuurwetenskaplikes probeer navolg het in die gebruik van wiskunde on tot ekonomiese waarhede te kom (Boulding, 1958:76). Die Neoklassieke ekonome het op sowel deduktiewe as induktiewe gebiede gepoog om hul wetenskap te kwantifiseer. Op die deduktiewe gebied is reeds in die inleiding aangetoon hoe Walras se soeke na ' $n$ bewys vir ' $n$ algemene ekonomiese ewewig gelei het tot die grootskaalse gebruik van gevorderde wiskunde in die ekonomie. Op die induktiewe gebied het die empirisisme in die begin van die eeu in die ekonomie posgevat met die werk van Fisher wat statistiese inferensie gebruik het om die determinante van rentekoerse te bepaal. Mettertyd het die gebruik van statistiek in die ekonomie sodanig ontwikkel dat 'n nuwe vakgebied, ekonometrie, onstaan het (Basson, 1990:76). Tot vandag toe is die onderliggende paradigma van ekonometrie die logiese positiwisme en empirisisme, en val die klem op vooruitskatting (Leamer, 1983:31).

Die opkoms van ekonometrie en die aanvaarding daarvan deur die hoofstroomekonome het tot 'n paradigmaverskuiwing binne die Neoklassieke skool gelei. Hierdie verskuiwing is deur Friedman en sy monetaristiese skool teweeggebring, 
en kan beskou word as 'n reaksie teen kritiek uit verskeie kringe teen die onrealistiese aannames wat die Neoklassieke teorie onderlê.

Friedman (1953) se reaksie op die kritiek teen die aannames wat die Neoklassieke teorie onderlê, is dat onrealistiese aannames maar geignoreer kan word. Friedman (1953) beweer dat "... the only relevant test of the validity of a hypothesis is comparison of its predictions with experience". Alle teoriee wat nie tot vooruitskattings kan lei nie, hoe realisties die aannames ook al, word deur Friedman as onwetenskaplik bestempel.

Nog 'n paradigmaverskuiwing binne die Neoklassieke teorie wat deur die kwantifisering van die ekonomiese wetenskap en die aanvaarding van die empirisisme van die ekonometrie teweeggebring is, is die Oostenrykse skool. Die Oostenrykse skool toon egter die teenoorgestelde reaksie as die Monetarisme op genoemde verwikkelinge: hul poog on die rol van wiskunde en ekonometrie ongedaan en nutteloos te maak deur die subjektiwisme aan te hang. Volgens die Oostenrykse skool is die nut wat 'n verbruiker uit 'n produk put, of die koste wat hy moet aangaan om dit te bekom, algeheel subjektief. Aangesien hierdie subjektiewe oordele nie meetbaar of waarneembaar is nie, kan die ekonomiese teorie volgens hulle nie in 'n wetenskaplike sin gemeet word nie (Hayek, 1967). Die Oostenrykse skool bring dus ' $n$ algehele breuk in die verbinding tussen ekonomiese werklikheid en ekonomiese teorie teweeg.

\subsection{Die Postmoderniste en die Strukturaliste}

Om die paradigmaverandering in die ekonomie wat tot die Postmodernisme en Strukturalisme gelei het te verstaan, is dit eers nodig on sekere ontwikkelinge in die wiskunde, soos die Chaosteorie en Katastrofe-teorie, kortliks te verduidelik Dié ontwikkelinge in die wiskunde is voorafgegaan deur ontdekkings in die fisi$\mathrm{ka}$, soos die relatiwiteitsteorie en die kwantumfisika, waarin Heisenberg se Onsekerheidsbeginsel belangrike implikasies vir wetenskapsbeoefening gehad het. Sonder om in die detail van hierdie ontdekkings in te gaan (die leser word verwys na Pagels, 1982), spreek Bronowski (1973:222) homself soos volg oor die gevolge van dié ontdekkings uit: "There is no absolute knowledge. And those who claim it, whether they are scientists or dogmatists, open the door to tragedy. All information is imperfect."

In die wiskunde is die besef dat daar geen universeel geordende geledinge bestaan nie, verkry deur die ontdekkings wat gemaak is op die terreine van die Katastrofe-teorie (Catastrophe Theory) en die teorie van Chaos (Woodcock \& Davis, 1978, Hall, 1992). Murphy (1991:145) dui spesifiek aan dat die wiskunde nie, soos die Neoklassieke ekonome veronderstel het, vry van vooronderstellings is nie, maar dat "Mathematics is embroiled in the judgements persons make about 
Die wiskunde en paradigmas in die ekonomiese wetenskap

reality, a long time before calculations are generated. Moreover, catastrophe theory recognizes that mathematics has a qualitative foundation".

Kasner en Newman (1989:361) beaam hierdie stelling en verklaar dat

We have overcome the notion that mathematical truths have an existence independent and apart from our own minds. Today mathematics is unbound. Non-Euclidean geometry is proof that mathematics is man's own handiwork, subject only to the limitations imposed by thought.

Gevolglik het dit begin duidelik word dat teorieë nie empiries of deur middel van wiskundige induksie as waar bewys kan word nie. Die volledige besef van die implikasies wat die Onsekerheidsbeginsel, Katastrofe-teorie en die teorie van Chaos vir die ekonomiese wetenskap inhou, het nog nie behoorlik algemeen posgevat nie. In die ekonometrie is daar 'n neiging om na 'a-teoretiese' modelle en Bayesiaanse modelle te beweeg (Zellner, 1971). Die opkoms van die postmodemistiese, strukturalistiese, en institusionalistiese skole in die ekonomie (waar besef word dat deduktiewe en induktiewe metodes van ondersoek nie vry is van waarde-oordele nie) dui daarop dat die ekonomiese wetenskap, soos tans beoefen deur die hoofstroom-ekonome, onder toenemende druk sal kom om hul verwysingsraamwerke te verander

Die postmodernistiese skool voer aan dat

... all knowledge is mediated by the human presence. Essential to postmodernism is a disavowal of 'metanarratives'. Gods, ultimate realities, structural imperatives and mathematical a prioris are examples of metanarratives (Murphy, 1991:145).

Die strukturalistiese skool, wat uit die Latyns-Amerikaanse Marxisme ontstaan het, word deur die Postmoderniste beïnvloed. Albei dié skole verwerp die algemeengeldigheid van enige ekonomiese teorie (veral die Neoklassieke teorie) en neig na relatiwisme. Volgens dié skole moet elke land sy eie ekonomiese realiteit ontdek, en behoort die normatiewe in die ekonomiese wetenskap beklemtoon te word. Die ekonomiese wetenskap kan dus volgens hulle nie, soos in die Neoklassieke ekonomiese teorie, losgemaak word van die omgewing of nie-ekonomiese omstandighede soos onder meer die vooroordele van die ekonoom nie (Taylor, 1990). In hierdie siening het die postmodernistiese en strukturalistiese skole heelwat in gemeen met die institusionalistiese skool.

\subsection{Die Institusionaliste}

Die verwerping van 'n objektiewe universeel-geldende werklikheid in die wiskunde, statistiek, fisika en ekonometrie en die gevolg dat die pilare wat die hoofstroom Neoklassieke ekonomiese teorie staande gehou het, toenemend besig is 
om in duie te stort, het tot ' $n$ herlewing van die 19de-eeuse institusionele skool in die ekonomie gelei. Om die redes hiervoor aan te toon, is dit nodig om die rigting en struktuur van die institusionele skool kortliks te bespreek.

Aan die einde van die vorige eeu het Thorstein Veblen (1899) en later John Commons (1924) reeds geargumenteer dat die aannames van die Neoklassieke ekonomiese teorie te onrealisties was.

Lowe (1976) verwys veral na die aanname van die 'rasionele ekonomiese mens' en stel dat hierdie aanname net kan geld onder omstandighede van armoede. Wanneer ' $n$ gemeenskap egter ontwikkel en meer welvarend is, kan nie-ekonomiese faktore ' $n$ groter invloed op gedrag hê, en kan menslike gedrag al meer onverklaarbaar raak. Lowe (1976:187) pleit gevolglik dat die ekonomiese wetenskap nie moet poog om die natuurwetenskappe na te boots nie, aangesien dit dan die risiko loop om 'n pseudo-wetenskap te word. Die onlangse bevindinge dat die wiskunde en die natuurwetenskappe nooit sonder vooronderstellings kan wees nie, en dat teorieë nie empiries as algemeen-geldend bewys kan word nie, verleen gesag aan dié stelling.

Veblen en sy navolgers het probeer om die gaping wat tussen die ekonomie en die sosiologie bestaan het te oorbrug. Die gaping tussen die sosiologie en die Neoklassieke ekonomiese teorie is soos volg deur Hahn en Hollis (1979) beskryf:

The stock distinction between economic and sociological theories of social action has been one between men as rational egoist versus men obedient to norms; ... economic theory characterizes the agent independently of his environment, which is not possible when the agent is a product of his environment.

Volgens Veblen (1899) is die kernbegrip wat die gaping tussen die abstrakte individu van die Neoklassieke ekonomie en sy sosiale omgewing oorbrug, die begrip van 'sosiale beheer'.

Sosiale beheer omvat onder meer die volgende fasette :

* Institusionele beheer oor individuele gedrag wat voortspruit uit gedragspatrone wat individue aanleer onder die geldelike aansporing van industriële instellings en werkgewers.

* Korporatiewe beheer oor markte wat voortspruit uit monopolistiese en geadministreerde markte wat die meeste ekonomieë kenmerk. Galbraith (1973) en Eichner (1980) verwys veral na mega-korporasies wat markte administreer met die doel om mededingers uit te hou, maar in die proses tot sowel werkloosheid as inflasie aanleiding gee. 
* Politieke beheer oor die ekonomie wat voortspruit uit die betrokkenheid van sentrale, streeks- en plaaslike owerhede in die ekonomie. Dugger (1983:80) wys daarop dat die besware nie teen die betrokkenheid van die owerhede per se is nie, maar eerder teen die ongekoördineerde en onkonsekwente wyse waarop dit plaasvind.

Die beleidsimplikasies van die institusionele skool is, in die lig van bostaande, die teenoorgestelde as dié van die Neoklassieke skool. Volgens die Institusionaliste is demokratiese, gekoördineerde beplanning deur die sentrale en laer owerhede nodig vir ekonomiese groei en ontwikkeling. Kritiek teenoor sentrale beplanning word soos volg deur die Institusionaliste beskou:

(T)he old belief that planning and its required social control would interfere with the exercise of man's 'free will' has become very difficult to hold in view of two conclusions : Man's 'free will' is shaped by the institutionally determined role he plays in the first place, and most of his markets now are administered by megacorps (Dugger, 1983:82).

Lowe (1977:23) stel voor dat die ekonoom se paradigma behoort te verskuif vanaf 'n positiwistiese siening, met die klem op vooruitskatting, tot 'n normatiewe wetenskap met die klem op sosiale beheer. Doelwitte vir 'n land se ekonomie moet deur middel van die politieke prosesse bepaal word, waarna ekonomiese, politieke en institusionele metodes gebruik moet word om te verseker dat die doelwitte bereik word. In die beplanning vir die proses gee Lowe eksplisiet erkenning aan die bydrae van die Neoklassieke ekonome om wiskundige tegnieke in die ekonomie te vestig. Lowe verwys na die noodsaaklikheid om hierdie instrumente, soos inset-uitset-matrikse, lineêre programmering en toegepaste algemene ewewigsmodelle te gebruik as hulpmiddel by die beplanningsproses. Anders as in die Neoklassieke benadering bly hierdie tegnieke slegs "hulpmiddels': dit word geen objektiewe toets vir teorieë nie, en die resultate van ekonomiese modelle word bloot as die gekwantifiseerde uitdrukking van die modelbouer se subjektiewe beskouings gesien.

\section{Die kwantifisering van die ekonomiese wetenskap en die Christelike paradigma}

Die kwantifisering van die ekonomiese wetenskap is 'n gegewe. Landreth (1976: 376) spreek homself daaroor soos volg uit:

During the 1950s and $1960 \mathrm{~s}$ the merits and demerits of mathematical economics were argued to a considerable extent in the professional journals. But these arguments have almost completely subsided, which suggests that mathematical economics is accepted as a useful and fruitful development in economic theory. 
In sy Nobelprys-rede bespreek Debreu (1991:2) al die voordele van die kwantifisering van die ekonomie, die vernaamste wat hy stel as dat "... in its mathematical form, economic theory is open to an efficient scrutiny of logical errors". Hy wys egter daarop dat ' $n$ moontlike gevaar van die kwantifisering daarin geleë is dat die wiskundige agtergrond wat van ekonome verwag word, hul kan beïnvloed om hul navorsing in ' $n$ bepaalde rigting te stuur; gevolglik kan die ekonomiese teorie in ' $n$ rigting ontwikkel wat min met die mens en sy behoeftes te make het. Debreu verwys na ' $n$ inhuman stance wat dikwels deur wiskundige ekonome ingeneem word.

Die bekommernis van Debreu dat die ekonomiese wetenskap in ' $n$ rigting ingedwing kan word deur die kwantifisering daarvan, word ook in die ander wetenskappe ervaar. Die Britse wiskundige, Stephen Hawking (1988:174), wys op die feit dat die wetenskap oor die algemeen gedurende die 19de en 20ste eeue te tegnies en wiskundig vir die filosowe geraak het. Hawking verwys na Wittgenstein wat in dié verband opgemerk het dat "the sole remaining task for philosophy is the analysis of language".

Die vraag onstaan hoe die Christenwetenskaplike, wat sy lewensfilosofie uit die Skrif put, die kwantifisering van die ekonomie moet hanteer, veral aangesien daar geen direkte relevante Skrifgegewens in hierdie verband is nie.

Ten eerste is die afwesigheid van direkte relevante Skrifgegewens geen aanduiding dat die Christenwetenskaplike antagonisties teenoor die kwantifisering van die ekonomiese wetenskap moet staan nie. God openbaar homself net soveel in sy Skepping, wat die wiskunde insluit, as in die Skrif. Galileo, wat deur die Roomse Inkwissisie in 1631 veroordeel is omdat hy in die wetenskap wou insluit wat nie direk in die Skrif geopenbaar is nie, openbaar reeds die Reformatoriese siening in sy stelling dat "Nor is God any less excellently revealed in Nature's actions than in the sacred statements of the Bible" (Drake, 1970:102). Die wiskundige en filosoof Leibniz was so gevul met die vreugde van God se Skepping soos hy dit in die wiskunde gevind het, dat hy uitgeroep het 'As God calculates, so the world is made!'

Die Christen-ekonoom kan ook iets van Leibniz se bewondering vir die wiskunde ervaar deur die gebruik van wiskunde in die ekonomie deur die Skrifperspektiewe van skepping, sondeval en verlossing te sien en te benader (Botha, 1991:116127). Hierdie benaderingswyse impliseer die erkenning dat die mens as beeld van God sy koninklike opdragte moet uitvoer in die beheersing van die ganse skepping. Tesame met die Bybelse antropologie van die mens as multi-dimensionele wese (en nie maar net homo economicus nie) behoort die Christen-ekonoom die mens dus binne sy samelewingsverbande, sy verhouding tot God en sy verhouding tot die natuur as 'n geheel te bestudeer (Botha, 1991:128-134). Enige 
ceteris paribus-aannames is dus onnodig. In die eerste afdeling is opgemerk dat dit vir die ekonoom nodig is om homself tot die wiskunde te wend om die komplekse realiteit van die mens se ekonomiese interaksie te verstaan. In hierdie opsig kan die wiskunde as 'n gawe beskou word - 'n gawe om te heers oor die skepping.

'n Verdere faset van die wiskunde as 'n gawe blyk uit die gevolge van die sondeval. Die sondeval het die mens se verhoudinge met God, sy medemens en die natuur versteur; die mens se begrip van sy werklikheid is as gevolg daarvan onvolmaak. Die sonde het die mens se rede so aangetas dat daar nie tot volle besef van al die interafhanklikhede en kompleksiteite in die skepping gekom kan word nie. Dit wat die mens wel deur middel van die wetenskap en die wiskunde te wete kan kom, is genade. Leith (1985:6) stel dat "The character of the world must forever escape attempts to constrain it within some a priori rational system constructed by human reasoning".

Dat die wiskunde ook onvolmaak is en deur die gevolge van die sondeval beperk word, is duidelik in die onlangse ontwikkelings in die wiskunde en wetenskap bevestig. Dié ontwikkelings dui op die noue verwantskap tussen die mens en wiskunde: dat die wiskunde 'n fundamentele menslike aktiwiteit is. God, wat alwetend is, het geen nut vir wiskunde nie: alle verbande in die skepping bly vir hom duidelik en word deur Hom bepaal. Die Christen-ekonoom kan dus nie anders nie as om sy wetenskap te beoefen in die wete dat die mens se rede nie alles is soos wat die Neoklassieke teorie voorgee nie.

Die Skrifperspektief van verlossing impliseer dat die Christen 'n normatiewe ekonoom behoort te wees. Om die skepping te herstel moet die mens sy doelstellings rig op wat behoort te wees, ook op die ekonomiese terrein.

Die belangrikste faset van die ontwikkelinge in die wiskunde en wetenskap waarna in afdeling 2 verwys is, is vir die Christen-ekonoom die gevolgtrekking wat gemaak kan word dat hy sy wetenskap kan uitleef onderhewig aan die Skriftuurlike riglyne oor skepping, sondeval en verlossing. Die Christen-ekonoom kan dit sodanig doen sonder om 'onwetenskaplik' voor te kom.

\section{Slot}

In hierdie artikel is aangetoon dat die wiskunde ' $n$ vername rol gespeel het in die wyse waarop paradigmas in die ekonomiese wetenskap verander het en nog steeds verander. Oor die wyse waarop die Christen-ekonoom hierdie rol van die wiskunde moet beskou, is aangetoon dat ontwikkelings in die wiskunde oor die afgelope dekades die paradigmas in die ekonomie nader laat beweeg het aan die Christelike paradigma, soos vervat in die Skrifperspektiewe van skepping, sondeval en verlossing. Hierdie verskuiwings is teweeggebring deur die ekonomiese 
wetenskap los te maak van die positiwisme en die saak vir 'n normatiewe benadering te versterk. In 'n komplekse werklikheid wat die mens nie na behore kan verstaan nie, maar wat hy tog as deel van die skeppingsopdrag moet beheers, is die wiskunde een van die instrumente waarmee die mens sy beheer kan uitoefen. Die klem behoort te val op 'instrument', want, soos Leith (1985:3) dit stel: "Scientific knowledge and activity are not an end in themselves but a part of our attempt to know our Creator and do his bidding."

\section{Bronnelys}

ARROW, K.J. \& DEBREU, G. 1954. Existence of an Equilibrium for a Competitive Economy. Econometrica, 22:265-290.

BASSON, E.T. 1990. The Historical Development of Econometrics. South African Journal of Economic and Management Sciences, 3:76-95.

BOTHA, M.E. 1991. Elementêre inleiding tot die Wetenskapsleer. Potchefstroom : PU vir CHO

BOULDING, K. 1958. Samuelson's Foundations: The Role of Mathematics in Economics. Journal of Political Economy, 56:76-87.

BRONOWSKI, J. 1973. The Ascent of Man. London : Futura.

CLOWER, R.W. 1965. The Keynesian Counterrevolution: A Theoretical Appraisal. (In HAHN, F. \& BRECHLING, F.P. eds. The Theory of Interest Rates. London : MacMillan. p. 61-87.)

CLOWER, R.W. \& LEIJONHUFVUD, A. 1975. The Coordination of Economic Activities: A Keynesian Perspective. American Economic Review, 65(2):182-188.

COMMONS, J.R. 1924. Legal Foundations of Capitalism. New York : McMillan.

DEBREU, G. 1991. The Mathematization of Economic Theory. American Economic Review, 81(1):1-7.

DIRAC, P.A.M 1963. The Evolution of the Physicist's Picture of Nature. Scientific American, 208:125-128.

DRAKE, S. 1970. Galileo Studies. Ann Arbour : University of Michigan Press.

DUGGER, W.M. 1983. Two Twists in Economic Methodology: Positivism and Subjectivism. American Journal of Economics and Sociology, 42(1):75-91.

DUNNE, P. 1991. Quantitative Marxism. Cambridge : Polity Press.

EICHNER, A.S. 1980. The Megacorp and Oligopoly. New York: ME Sharpe.

FRIEDMAN, M. 1953. The Methodology of Positive Economics ( $m$ Friedman, M. ed. Essays in Positive Economics. Chicago : University of Chicago Press. pp. 3-50.)

GALbRAITH, J.K. 1973. Economics and the Public Purpose. Boston : Houghton Mifflin.

HAHN, F.H. \& HOLLIS, M. eds. 1979. Philosophy and Economic Theory. Oxford : Oxford University Press.

HALL, N. 1992. The New Scientist Guide to Chaos. London: Penguin.

HAWKING, S.W. 1988. A Brief History of Time. London: Bantam Press

HAYEK, F.A. 1967. Studies in Philosophy, Politics and Economics. New York: McMillan.

HODGSON, G.M. 1990. Economics and Institutions. Cambridge : Polity Press.

KAKUTANI, S. 1941. A Generalization of Brouwer's Fixed Point Theorem. Duke Mathematical Journal, 8:457-459.

KASNER, E. \& NEWMAN, J.R. 1989. Mathematics and the Imagination. Washington Tempus-Microsoft Press

KEYNES, J.M. 1936. The General Theory of Employment, Interest and Money. London McMillan. 
Die wiskunde en paradigmas in die ekononiese wetenskap

LASTIS, S. 1976. Method and Appraisal in Economics. Cambridge : Cambridge University Press.

LANDRETH, H. 1976. History of Economic Theory: Scope, Method and Content. Boston : Houghton Mifflin.

LEAMER, E.E. 1983. Let's Take the Con out of Econometrics. American Economic Review, 73:31-43.

LEIJONHUFVUD, A. 1968. On Keynesian Economics and the Economics of Keynes. New York : Oxford University Press.

LEITH, T.H. 1985. Faith and Scientific Inquiry. Potchefstroom Studies in Christian Scholarship no. 12. Department of Philosophy of Science.

LOWE, A. 1976. The Path of Economic Growth. Cambridge : Cambridge University Press.

LOWE, A. 1977. On Economic Knowledge. 2nd ed. Chicago : University of Chicago Press

LUCAS, R.E. 1972. Expectations and the Neutrality of Money. Journal of Economic Theory, 4:103-124.

MURPHY, J.W. 1991. Catastrophe Theory: Implications for Probability. American Journal of Economics and Sociology, 50(2): 143-148

PAGELS, H.R. 1982. The Cosmic Code. London: Penguin

PYATT, G. 1988. A SAM Approach to Modelling. Journal of Policy Modelling, 10(3):327352

SHAW, G.K. 1988. Keynesian Economics : The Permanent Revolution. London : Edward Elgar.

STONE, J.R.N. 1986. The Accounts of Society. Journal of Econometrics, 1:1-8

TAYLOR, L. 1990. Socially Relevant Policy Analysis : Structuralist Computabie General Equilibrium Models for the Developing World. Cambridge MA : MIT Press.

VEBLEN, T B. 1899. The Theory of the Leisure Class : An Economic Study of Institutions. New York: McMillan.

WOODCOCK, A. \& DAVIS, M. 1978. Catastrophe Theory. London : Penguin

WALRAS, L. 1874. Elements d'économie politique pure. Lausanne : Corbaz (Vertaal as Elements of Pure Economics. 1954. Chicago : Irwin.)

ZELLNER, A 1971. An Introduction to Bayesian Inference in Econometrics. New York John Wiley 